\title{
The Role of Public Participation in Governance towards Achieving Sustainable Development. Part 1
}

\author{
Maurice S. Nyaranga $\bowtie$, Chen Hao, Duncan O. Hongo \\ Jiangsu University, \\ Zhenjiang, Jiangsu, P.R. China, 212013 \\ $\triangle$ simiyunyaranga@gmail.com
}

\begin{abstract}
Public participation aimed at improving the effectiveness of governance by involving citizens in governance policy formulation and decision-making processes. It was designed to promote transparency, accountability and effectiveness of any modern government. Although Kenya has legally adopted public participation in day-to-day government activities, challenges still cripple its effectiveness as documented by several scholars. Instead of reducing conflicts between the government and the public, it has heightened witnessing so many petitions of government missing on priorities in terms of development and government policies. Results show that participation weakly relates with governance hence frictions sustainable development. Theoretically, public participation influences governance efficiency and development, directly and indirectly, thus sustainable development policy and implementation depends on Public participation and good governance. However, an effective public participation in governance is has been fractioned by the government. Instead of being a promoter/sponsor of public participation, the government of Kenya has failed to put structures that would spur participation of citizens in policy making and other days to activities. This has brought about wrong priority setting and misappropriation of public resources; The government officials and political class interference ultimately limit public opinion and input effects on decision-making and policy formulation, which might be an inner factor determining the failure of public participation in Kenya. The study suggests the need for strengthening public participation by establishing an independent institution to preside over public participation processes.
\end{abstract}

Keywords: public participation, government, governance, sustainable development, institutionalization

Conflicts of interest: The authors declared no conflicts of interest.

Article history:

The article was submitted on 01.09.2021. The article was accepted on 01.10.2021

For citation: Nyaranga M.S., Hao Ch., Hongo D.O. The Role of Public Participation in Governance towards Achieving Sustainable Development. Part 1. RUDN Journal of Public Administration. 2021;8(4):395-404. DOI: 10.22363/2312-8313-2021-8-4-395-404

(C) Nyaranga M.S., Hao Ch., Hongo D.O., 2021

(c) () This work is licensed under a Creative Commons Attribution 4.0 International License https://creativecommons.org/licenses/by/4.0/ 


\section{Introduction}

Governance has undergone significant transformations from the typical hierarchical, authoritarian, dictatorial, and imperial systems to democratic and collaborative structures. The third wave for democratization dealt with the consolidation of democracy. It provided a new model of public administration and policies to encourage citizens' participation in the government decision-making process. Participatory governance, therefore, is a system of government that engages citizens in both voting and deliberation on matters involving management. It creates an interactive platform between citizens and government, as the latter roles up the sponsoring agency. Participatory governance implies that citizen participation is the back-borne for democracy [1-5]. Participation provides a platform for an all-inclusive government with a strengthened democracy. It gives people a voice on issues that touches their daily life.

The change in the complexity of needs and rapid structural adjustments in the modern world calls for a robust and holistic kind of governance that representative democracy cannot exist in absolute sort. There is a need to have an interactive relationship between the government and the people. The mere aspect of vote casting insignificantly steers decision-making by the political class at the expense of running consultative forums and other research mechanisms for citizen involvement. The process invokes much than just a rationale for political, democratic, ethical, pragmatic, and social reasoning. PP provides a platform for such a structurally organized exchange of ideas [6-8]. Societies are increasingly becoming complex, cropping up new needs that require comprehensive consultation for better decisions/policies that sustain the suggested solution.

Participation by citizens has been primarily motivated by the challenges caused by the limitations of representative governments to deliver on needful services, account for public resources, ineffective utilization of public resources, and skewed priority setting [9;10]. Additionally, the growing need for change of governance structures and institutions to make the government more efficient and effective has been tremendous. Moreover, political leaders in government are seeking public endorsements to policies and ideas to buttress what they have in place. Some are also seeking legitimacy for unpopular government policies [9; 11-14]. Having a government as one sole solution provider has proved to be weak. Not all ideas lie with government officials. Besides, resources are co-shared, and citizens have a right as well as the responsibility to know how to use public funds efficiency. Therefore, engaging citizens in resource appropriation is vital to avoid missing the priorities in development and also to enhance accountability.

Ensuring collaborative and flexible government that steers multiple stakeholders towards the installation of a responsive government and consultative at all levels continually remains the prerequisite for sustainable development. Additionally, champions of sustainable development postulate that good governance and the rule of law is critical in the development agenda. Consequently, complex societal problems can only be addressed through a collaboration of all sectors to redesign operational structures that combine resources, knowledge, and expertise from a broad spectrum of players. In this process, the government plays a 
crucial role in establishing a platform and formulating engagement rules. Furthermore, timely dissemination of information also contributes to citizen-centred governance. All these strategies lead to strong legitimacy and public trust, effective, efficient, and equitable delivery for high-quality public service $[3 ; 6 ; 15-18]$. An effective government is as well efficient and responsive to people's needs. Challenges, opportunities and priorities in development programs are inevitable. In every problem that a government wishes to address, citizens are both recipients and stakeholders for solution-seeking.

Globally, governments engender the protection of human rights and fundamental freedom while promoting the rule of law, which implies that their people and institutions are subject and accountable to the law. To uphold the principles of the rule of law, Kenya implemented the 2010 constitution, which has so far provided a basis for governing. However, PP, especially in policymaking and implementation, has negatively been underscored, with the most extant challenge being unwillingness by government project officials and the political class to engage citizens. Besides, the inability of the citizens to deliberate on government issues due to scarce information and lack of empowerment programs like civic education also affect the level of citizen participation in the governance process $[19 ; 20]$. Such challenges have affected the relevance and effectiveness of the PP process.

This study fills the gap by investigating the relationship between PP and government and the impact on sustainable development. Further, the study determines factors for improving such a relationship. Specifically, the study explores how sustainable development is affected by PP and the government as the sponsoring agency, and factors that promote a conducive environment for better PP in governance.

The approach regarding the SEM modelling initiates from a CFI test for parameter/constructs reliability, which is succeeded by the path- and regressionanalysis. The results demonstrate some significant influences of PP on governance and sustainable development, and also, factors such as public awareness and their willingness significantly determine the participation.

Moreover, the study extends the existing literature by incorporating the effect of the relationship between PP and governance on sustainable development. Also, the incorporation of the PCA component to aggregate an interactive construct of civic involvement and Government for relations effect analysis adds to the extant literature. It so does the vital revelation that PP is an inevitable state-policy making process.

The rest of the paper is sectioned as follows: The proceeding section tackles the literature review, chapter 3 the data and Methodology of study, chapter 4 results and analysis, chapter 5 discussions, and policy conclusion.

\section{Literature Review}

In the last two decades, there have been deliberate efforts to create a robust government-citizen working relationship for sustainable development. Public participation forums facilitate citizens' pro-activeness in designing government 
programs and policy decision making. Participation by citizens primarily is motivated by the ineffective centralized system to deliver the needful services to citizens, lack of accountability, improper utilization of public resources, and skewed priority setting. The emphasis on change of governance structures and institutions to make the government efficient and effective has been on the increase $[4 ; 5 ; 21]$ adds that political leaders and government officials are also seeking public endorsements to policies and ideas to support what they have in place. Some are seeking legitimacy for unpopular government policies.

Moreover, public participation has gained roots across the world. Nations have embraced PP to curb government-citizen conflict that has been emerging from marginalization and uneven distribution of government services. Although the aim was to install open, accountable and participatory governance, nothing much towards achieving participatory governance has been done. Governments handle public participation as merely a customer consultation as opposed to engaging with citizens as equal partners in governance. Public participation is still a restricted affair with most powers yet to be practically surrendered to the people. Other barriers to participation include; inadequate enforcement of citizen engagement laws, inadequate information to the public, unawareness among citizens of their important responsibility, among others [22; 23]. Yami [24] adds that though the government has made efforts to have citizen engagement in the policy-making process, the input by citizens is ignored in decision-making.

Citizen engagement promotes three values of democratic governance: effectiveness, legitimacy, and social justice. The significant change brought about by advanced technologies has intensified demand for creating a participatory system of governance considered competent. The traditional hierarchical system of governance, which primarily entails anarchy governments, is under criticism. Citizens' today demand to have a government for the people and by the people. Governments that have not adopted democratic forms of governance have been described as illegitimate. In a democratic society, people are the source of authority. Public participation strengthens the government-citizen relationship. Though different governments have been continuously seeking legitimacy, social justice and effectiveness, lack of organized leadership, consensus and limited powers for stakeholders to engage freely have haunted the process. Many political leaders are conceding to the fact that it is not about the government to provide solutions to all problems that arise in society. Most of the current governments are not holistic. Hence partnership with the public is vital in seeking answers to societal issues [25].

Kyohairwe adds that participatory governance in local democracy is a community-driven approach to accountability. In Uganda, for instance, public meetings are held at the village level to deliberate on the appropriation of public resources. Later, government reports on expenditures are discussed in these public meetings, and assessment is done on the excess according to the budget. The practice has facilitated accountability in government use of public resources.

Public participation can sort out many challenges if well handled. According to Ling Li [26], engaging citizens on environmental issues has reduced industrial pollution in China. Though it is at the embryonic stage and has not been widely practiced, there is a noticeable change and would be useful if well handled by the 
government. There is a need for the government to create a conducive atmosphere for engaging citizens through amending laws that would accommodate this aspect on better grounds. Sharing data through media is equally important as it empowers citizens to engage with an informed point of view. In Kenya, no unique situation as citizen engagement has suffered setbacks. They include; Unwillingness among the people, lack of political goodwill, participation ineptness, political interference, demand for incentives, and lack of time for public participation by the citizens. Besides, citizens lack civic education and appropriate communication channels since the government cut the chains to keep citizens in the dark regarding government intentions. Creating awareness about development programs enables citizens to participate positively in shaping development [19; 27]. J. further notes that much energy, resources and time have been wrongly dedicated to the whole process of seeking public opinion. Hence, creating waste as the government still offers solutions that do not meet the questions raised by the subjects. The information, sometimes, as Yami [24] puts it, just stops at the function of participation. The outcome in terms of policy does not reflect public opinions making the process a disappointment.

The above works of literature, however, delve much into the importance of citizen involvement in governance and the challenges facing this aspect of public participation. This study adds the existing body of knowledge on how to counter the challenges and enhance the role of public participation in governance for sustainable development.

Theoretical Literature. The concept of PP which originates from the sociopolitical discourse involves the interaction between the people and the government. Such interaction encompasses public administration and development theories regarding the involvement of the citizens in governance. Hence, the study employs two approaches (theories) to explain the interaction. They include the Social System model theory and the Contingency Theory which consequently provides the evolution of the hypothetical assumption of this paper.

The Social System model implies the existence of significant linkages amid the administrative system components (government) and the external environment (stakeholders/public). That is, inputs, processes, output, and feedback as core elements of the social system and very critical in the execution of public laws, and promoting functionality in governance. This theory postulates an organization/government as a cooperative or collaborative system that facilitates desirable outcomes while limiting the negative externalities [28-30]. In this regard, the study hypothesized that (H1-) PP in government policy formulation and implementation promotes the utility of public resources and sustainable governance.

By contingency theory, it regards that there is no best way to lead or make a decision in any cooperation. However, the actions are always dependent upon the internal and external environment. Some authors consider this theory as a dominant, theoretical, rational and open system model at the structural level of analysis in organization theory and with the underlying assumption as the environment for organizational operations determines the best way to organize. Contingency theory is the relationship between two phenomena, and this implies that if there exists some 
significant relationship amid, then the significant behavioral connection may be concluded from the other. $[31 ; 32]$. With this, the study hypothesized that $(\mathrm{H} 2-)$ government and civic involvement in the state policymaking process significantly cause sustainable development and that (H3), PP correlates with sustainable development. Consequently, (H4) the mutual correlation between PP and Good Governance supports Sustainable Development.

\section{Methodology}

Dataset. The set is primary data collected via a questionnaire that was prudently structured to objectively collect information regarding the aims of the current study. The population targeted in this case, was adult individuals from Bungoma County in the Republic of Kenya, who are at the age of 18 years and/or above and having internet access ${ }^{1}$. The study adopted proportionate stratified random sampling, and since the sample population is more than 10,000 citizens, the study adopted the Fisher, 1983 proposition [9] in selecting the sample size. That is, according to Fisher, the size ( ) is given as;

$$
n=\frac{z^{2} p q}{e^{2}}=\frac{1.96^{2}(0.5 \times 0.5)}{0.05^{2}}
$$

Where is the $95 \%$ confidence interval, e-- the sampling error, the maximum variability of the population at $50 \%$ and $=(1-)$. Concerning equation 1 , the suitable size is therefore 384. However, due to the many survey-response related discrepancies, this study targeted 400 respondents. Furthermore, since regressions mostly in Stata requires a full sample, we randomly selected a total of 384 filled sample and in support of Fisher, 1983 [33]. The sample size is thus a set of both endogenous and exogenous variables.

Therefore, the endogenous variable is latently designated by sustainable development which, in this study, is parameterized by both priority and development funds. Priority is based on the inquiry on the respondents regarding whether the county government has given priority to the essential needs of citizens in terms of development while development funds parameter based on whether the county government/state allots and feasibly manages the funds and resources for the development of essential development and infrastructural projects. However, they all were calibrated based on the 5-point Likert-type scale (with range 5strongly agree to 1-strongly disagree).

The exogenous set is on the other hand constituted by both public participation (PP) and Government (G). By the former, parameterization is by public participation awareness, understanding the public participation process, whether people need facilitation, whether there is willingness/goodwill for public participation by the people, and if they know stages of the budgeting process. That

\footnotetext{
${ }^{1}$ The study presumed that all persons above 18 years have access to the internet and is adult person as implied by the legal provision in the 2010 constitution of Kenya: Article 260 of the 2010 Kenyan constitution stipulates an adult person as any person having attained the age of eighteen years. Demography-wise, the Kenya National Bureau of Statistics annual (2016) projected 701,151 persons of eighteen years and above by the year 2018 as to be living in Bungoma County.
} 
is; respectively, whether (a) the respondent has a grip with PP process, (b) whether they are aware that PP exists, (c) whether they wish they should be facilitated to participate or attend any PP event, (d) the respondents out of own volition participates or attends the process and (e) sthe has the knowledge and an understanding of the budgeting process/stages. Still, the variables were all anchored on the 5-point Likert-type scale (from 5-strongly agree to 1-strongly disagree).

The endogenous variable is the government that captures the interest of the state in the PP process. It is anchored on a set of parameters, including creating an enabling environment for PP, designating public venues for PP, and whether there is political interference on PP by government officials. Besides, it also depends on whether the government gives timely notification for PP events and adherence to PP legal provisions by the government. The researcher will depend on the following statements to guide the generalization on government:

a) The County Government has created the necessary enabling environment/ conditions for PP

b) There exist designated or fixed close range venues for PP

c) Political interference to the process of PP is inevitable

d) There is usually a timely notice on the PP process

e) People subjectively feel satisfied with how the county government upholds and adheres to the legal provision by the 2010 constitution concerning plausible PP in state affairs.

Further, all the parameters except PP law still are calibrated from the 5-point Likert-type scale (with 5-strongly agree to 1-strongly disagree). PP law parameter was, on the contrary, measured binomially with an individual acknowledging for the existence of the law or if put in place taking yes (i.e., 1-yes or 0 -otherwise). The variables in this study have been widely implored in the extant literature and showed positive effects or findings. Aulich [22] and Okello [23] have discussed awareness and understanding of PP. Ronoh [19] on the other hand discussed political interference, goodwill from both the public and government, people's understanding of the PP process, government designating venues for participation, and citizens demanding incentives or facilitation. A. Fung [25] advanced the idea of awareness and empowering citizens with information on matters of governance and policymaking. Huang [34] and Yami [24] add to the aspect of funding and the interference by government officials in the decision-making process, respectively. In these studies, researchers have used the variables to advance or discuss both the challenges and opportunities for PP in governance and development. However, in this study, the variables have been treated as indicators hence aggregated under PP, government, or sustainable development.

It is also important to note that the three main variables have Cronbach's alpha statistics as $0.76,0.78$, and 0.68 (see part 2 Table 1) for PP, government, and sustainable development, respectively. This reliability is an indication of an averagely well reliable data set for further analysis, which initiates by the investigation of their physical characteristic with results presented in Table 1.

What proceeded is the empirical methodology by the current study and incorporated the analysis of the confirmatory factor analysis (CFA) test to validate the significance of the respective constructs in explaining the existing relationship 
or aims of the study and presented these results in part 2 table 1 . From the CFI test, path analysis was executed as in Figure 1 to model the likely underlying causality direction amid the variable, and finally the simultaneous equation modelling. The consequence was the final operationalization of the objectives in finding the relationship between PP and government, and the impact of both public involvement and government on sustainable development whose findings are presented in Figure 2. Therefore, the analysis and interpretation of these results are addressed in the next section.

However, it is essential to report that our design innovatively adds to the classical structural modelling exploration and strengthening the PP knowledge while in search of the robustness for the results. That is, we employ the principal component analysis and the KMO that enhances the construction of an informative, interactive index amid PP and Government which, allows final impact analysis on sustainable development while pleasantly offsetting autocorrelation problem, but preserving the underlying information in individual parameters. In this manner, the study avoided spurious regression that would be the case when largely correlated parameters are incorporated in a single regression.

To the next part. In the second part of the article there is full description of our findings and results (Data Collection; Description of the Study; Models), discussion of the findings, conclusion and describing of some limitations of the study. There are some recommendations based on findings.

\section{REFERENCES}

1. Holmes B. Citizens' Engagement in Policymaking and the Design of Public Services. Parliamentary Library. Parliament of Australia; 2011.

2. Huntington S.P. Democracy's Third Wave. Journal of democracy. 1991;2(2):12-34.

3. Molokwane T., Lukamba T. Citizen Involvement in the Formulation of Public Policy. The 3rd Annual International Conference on Public Administration and Development Alternatives 04-06 July 2018, Stellenbosch University, Saldahna Bay, South Africa; 2018.

4. Wampler B. Participatory Budgeting: Core Principles and Key Impacts. Journal of Public Deliberation. 2012;8(2):12-13.

5. Wampler B., McNulty S. Does Participatory Governance Matter? Exploring the Nature and Impact of Participatory Reforms. 2011. URL: https://www.alnap.org/system/files/ content/resource/files/main/cusp-110108-participatory-gov.pdf. Accessed: 22.09.2021.

6. The Road to Dignity by 2030: Ending Poverty, Transforming All Lives and Protecting the Planet -Synthesis Report of the Secretary-General On the Post-2015 Agenda. URL: https://reliefweb.int/report/world/road-dignity-2030-ending-poverty-transforming-all-livesand-protecting-planet-synthesis. Accessed: 22.09.2021.

7. Burton N.W., Turrell G., Oldenburg B. Participation In Recreational Physical Activity: Why Do Socioeconomic Groups Differ? Health Education \& Behaviour. 2003;30(2):225-244.

8. Korfmacher K.S. The Politics of Participation in Watershed Modelling. Environmental management. 2001;27(2):161-176.

9. Goetz A.M., Gaventa J. Bringing Citizen Voice and Client Focus into Service Delivery. Institute of Development Studies; 2001.

10. Narayan D., Chambers R., Shah M.K., Petesch P. Voices of the Poor: Crying out for Change. Washington, D.C: World Bank; 2000.

11. Balloch S., Taylor M. Partnership Working: Policy and Practice. Policy Press; 2001.

12. Barnes M., Prior D. Private Lives as Public Policy. Venture Press; 2000.

13. Pritchett L., Woolcock M. Solutions when the Solution is the Problem: Arraying the Disarray in Development. World Development. 2014;32(2):191-212. 
14. Ruane S. Public-private Partnerships - the Case of PFI. Partnerships, New Labour and the Governance of Welfare. Glendinning C., Powell M., Rummery K. eds. Bristol: Policy Press; 2002.

15. Next Steps in Addressing Ireland's Five-Part Crisis: Combining Retrenchment with Reform. 2009. NESC. URL: nesc.ie/publications/next-steps-in-addressing-irelands-five-partcrisis-combining-retrenchment-with-reform/. Accessed: 22.09.2021.

16. 21st Century Technologies - Promises and Perils of a Dynamic Future. OECD; 1998.

17. Public Participation Guide: Workshops. United States Environmental Protection Agency. URL: https://www.epa.gov/international-cooperation/public-participation-guide-workshops. Accessed: 29.08.2021.

18. World Economic and Social Survey 2013: Sustainable Development Challenges. UNDESA. 02.07.2013. URL: https://www.un.org/en/development/desa/publications/world-economicand-social-survey-2013-sustainable-development-challenges.html. Accessed: 22.09.2021.

19. Ronoh G., Mulongo S.L., Kurgat, A. Challenges of Integrating Public Participation in the Devolved System of Governance for Sustainable Development in Kenya. Moi University: Eldoret, Kenya; 2018.

20. Rossouw M. Public Participation: An Imperative for Governance and Human Rights Lessons From South Africa. 2019. URL: http://futureafricaforum.org/2019/03/04/publicparticipation-an-imperative-for-governanceand-human-rights-lessons-from-south-africa/. Accessed: 22.09.2021.

21. McNulty S.L., Wampler B. Participatory Governance. Emerging Trends in the Social and Behavioral Sciences: An Interdisciplinary. Searchable, and Linkable Resource. 2015;1:1-14.

22. Aulich C. From Citizen Participation to Participatory Governance. Commonwealth Journal of Local Governance. 2009;2:44-60.

23. Okello N., Beevers L., Douven W., Leentvaar J. The Doing and Undoing of Public Participation During Environmental Impact Assessments in Kenya. Impact Assessment and Project Appraisal. 2009;9(3):216-226.

24. Yami M., Van A.P., Hauser M., Schut M., Pali P. Participation without Negotiating: Influence of Stakeholder Power Imbalances and Engagement Models on Agricultural Policy Development in Uganda. Rural Sociology. 2018;84(2):340-415.

25. Fung A. Putting the Public back into Governance: the Challenges of Citizen Participation and its future. Public Administration Review. 2015;75(4):513-522.

26. Ling L.X., Bin C., Luxi S. Public Participation in Achieving Sustainable Development Goals in China: Evidence from the Practice of Air Pollution Control. Journal of Cleaner Production. 2018;201(10):499-506.

27. Njagi T., Kinyumu N,. Kirimi L. Farm Household's Participation in Governance: Lessons from Devolved Systems in Kenya. IDEAS. URL: https://ideas.repec.org/p/ags/iaae18/ 276006.html. Accessed: 22.09.2021.

28. Lamidi K.O. Theories of Public Administration: an Anthology OF Essays. International Journal of Politics \& Good Governance. 2015;6(6.3):1-35.

29. Manithaneyam S. Theory of Administration; 2003.

30. Taylor C. Social Theory as Practice. Philosophy and the Human Sciences: Philosophical Papers 2. Taylor C. (eds.). Cambridge: Cambridge University Press; 1985.

31. Betts S.C. Contingency Theory: Science or Technology. Journal of Business and Economic Research. 2005;1(8):30-44.

32. Schoech I. Contingency Theory. Alabama: UTA Press; 2006.

33. Carter R.L. Solutions for Missing Data IN Structural Equation Modeling. Research \& Practice in Assessment. 2006; 1:1-6.

34. Huang W., Mary F. Citizen Participation in Local Government Decision Making: The Role of Manager Motivation. Review of Public Personnel Administration. 2015;36(2):188-209.

\section{Information about the authors:}

Maurice S. Nyaranga - Student of the Department of State and Municipal Management, Jiangsu University (People's Republic of China) (ORCID ID: 0000-0003-1127-0789) (e-mail: simiyunyaranga@gmail.com).

Chen Hao - PhD, Professor, School of Management, Jiangsu University (People's Republic of China) (ORCID ID: 0000-0002-2581-2940) (e-mail: zjchenghao@ujs.edu.cn).

Duncan O. Hongo - Master (Statistics), School of Management, Jiangsu University (People's Republic of China) (ORCID ID: 0000-0003-1069-7238) (e-mail: dancanome@yahoo.com). 


\title{
Роль участия общественности в управлении для достижения устойчивого развития. Часть 1
}

\author{
М.С. Ньяранга $₫$, Ч. Хао, Д.О. Хонго \\ Университет Цзянсу, \\ 212013, КНР, Чжэньизян, Цзянсу \\ \simiyunyaranga@gmail.com
}

\begin{abstract}
Аннотация. Участие общественности направлено на повышение эффективности управления путем вовлечения граждан в процессы разработки политики, управления и принятия решений. Такой подход был разработан для обеспечения прозрачности, подотчетности и эффективности любого современного правительства. В статье показано, что несмотря на то, что в Кении законодательно закреплено участие общественности в повседневной деятельности правительства, возникающие проблемы по-прежнему подрывают эффективность такого участия, что было убедительно подтверждено рядом ученых. Вместо того, чтобы уменьшить конфликты между правительством и общественностью, нередко правительства упускают из виду этот аспект в рамках развития и формировании государственной политики. Результаты исследования показывают, что участие граждан слабо связано с управлением, что препятствует устойчивому развитию. Теоретически участие общественности прямо и косвенно влияет на эффективность управления и его развитие. Таким образом, политика устойчивого развития и ее реализация зависят от участия общественности и надлежащего управления. Однако эффективное участие общественности в управлении было ограничено правительством. Вместо того, чтобы инициировать и поддерживать участие общественности, правительство Кении не смогло создать структуры, которые стимулировали бы участие граждан в разработке политики. Это привело к неправильной установке приоритетов и незаконному присвоению государственных ресурсов. Государственные чиновники и вмешательство политического класса в конечном итоге ограничивают общественное влияние на принятие решений и формулирование политики. Авторы указывают на необходимость усиления общественного участия путем создания независимого учреждения, которое будет руководить процессами участия общественности.
\end{abstract}

Ключевые слова: Кения, общественное участие, правительство, управление, устойчивое развитие, институционализация

Заявление о конфликте интересов: Авторы заявляют об отсутствии конфликта интересов.

\section{История статьи:}

Статья поступила в редакцию: 01.09.2021. Статья принята к публикации: 01.10.2021.

\section{Для цитирования:}

Nyaranga M.S., Hao Ch., Hongo D.O. The Role of Public Participation in Governance towards Achieving Sustainable Development. Part 1 // Вестник Российского университета дружбы народов. Серия: Государственное и муниципальное управление. 2021. Т. 8. № 4. С. 395-404. DOI: $10.22363 / 2312-8313-2021-8-4-395-404$

\section{Информация об авторах:}

Морис С. Ньяранга - студент факультета государственного и муниципального управления Университета Цзянсу (Китай) (ORCID ID: 0000-0003-1127-0789) (e-mail: simiyunyaranga@gmail.com). Чэнь Хао - доктор наук, профессор школы менеджмента Университета Цзянсу (Китай) (ORCID ID: 0000-0002-2581-2940) (e-mail: zjchenghao@ujs.edu.cn).

Дункан О. Хонго - магистр школы менеджмента Университета Цзянсу (Китай) (ORCID ID: 0000-0003-1069-7238) (e-mail: dancanome@yahoo.com). 